\title{
Morphological and pathogenic characterization of Fusarium oxysporum in lulo (Solanum spp.)
}

\author{
Caracterización morfológica y patogénica de Fusarium oxysporum en \\ lulo (Solanum spp.)
}

Yohana Patricia Anama1; Ricardo Andrés Díaz ${ }^{2}$; David Duarte-Alvarado ${ }^{3}$; Tulio César Lagos-Burbano ${ }^{4}$

\begin{tabular}{ll}
\hline \multicolumn{1}{c}{ ARTICLE DATA } \\
\hline 1 Researcher, IAF. Universidad de Nariño, Pasto, \\
Colombia, patrikfame9611@gmail.com \\
$2 \quad \begin{array}{l}\text { Researcher, IAF. Universidad de Nariño, Pasto, } \\
\text { Colombia, ricardodiazoliva@gmail.com }\end{array}$ \\
3 Researcher, M.Sc., Grupo de Investigación en \\
Producción de Frutales Andinos, Pasto, Colombia, \\
deduartea@unal.edu.co \\
$4 \quad \begin{array}{l}\text { Professor, Ph.D., Universidad de Nariño, Pasto, } \\
\text { Colombia, tclagos3@yahoo.com }\end{array}$ \\
\hline
\end{tabular}

Cite: Anama, Y.; Díaz, R.; Duarte-Alvarado, D.; LagosBurbano, T. (2021). Morphological and pathogenic characterization of Fusarium oxysporum in lulo (Solanum spp.). Revista de Ciencias Agrícolas. 38(1): 2037. doi: https://doi.org/10.22267/rcia.213801.142

Received: November 162020. Accepted: January 282021.

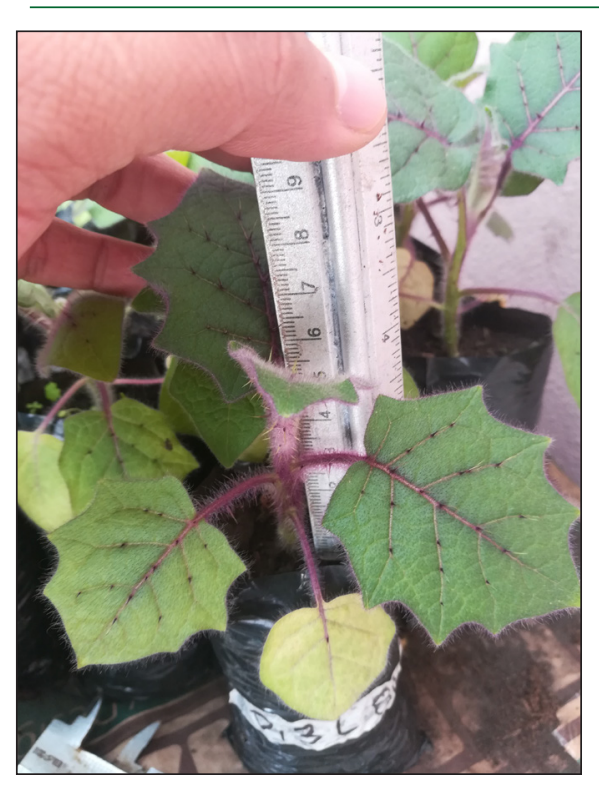

ABSTRACT

Fusarium oxysporum is one of the most limiting fungal pathogens of lulo crop. To determine its pathogenicity, this work morphologically and pathogenically characterized F. oxysporum isolates from different lulogrowing municipalities of the Department of Nariño. Twenty isolates were evaluated through a completely randomized design with two factors and three replicates per treatment, including a control. The first factor corresponded to 20 isolates of $F$ oxysporum and the second to 10 lulo genotypes. The morphological characterization involved determining growth rate (GR), color (CO), mycelial type (MT), medium coloration (Mc), shape $(\mathrm{Sh})$, size $(\mathrm{S})$, number $(\mathrm{N})$ of macroconidial $(\mathrm{Ma})$ and microconidial (Mi) septa, presence of chlamydospores (PC), and chlamydospore shape (CS). Moreover, the pathogenic characterization was based on the incubation period (IP), absolute growth rate (AGR), disease severity (DS), disease incidence (I), and vascular discoloration (VD). The morphological characterization demonstrated that all isolates corresponded to $F$. oxysporum. For IP, genotype G1 showed the lowest average at 18 days. For AGR, genotype G2 had the lowest height increase at $0.05 \mathrm{~cm}^{-d a y}{ }^{-1}$. For DS, genotype G1 reached the highest severity level (level 9) and a disease incidence of $100 \%$. This study provides the first report of the special form of F. oxysporum f. sp. quitoense in Nariño. Solanum hirtum, Solanum sessiliflorum, and Solanum estramonifolium were resistant to the isolates evaluated, demonstrating that wild species should be considered as sources of resistance for breeding programs aiming to obtain resistant commercial genotypes.

Keywords: Incidence; Severity; Solanum hirtum; Solanum sessiliflorum; Solanum estramonifolium.

\section{RESUMEN}

Fusarium oxysporum es uno de los hongos más limitantes en la producción del cultivo de lulo y con el fin de conocer su patogenicidad, este trabajo caracterizó morfológica y patogénicamente aislamientos 
provenientes de diferentes municipios productores del departamento de Nariño. Se evaluaron 20 aislamientos de F. oxysporum bajo el Diseño Completamente al Azar con dos factores y tres repeticiones por tratamiento más un testigo. El primer factor corresponde a 20 aislamientos de F. oxysporum y el segundo a 10 genotipos de lulo. Para la caracterización morfológica se evaluó la velocidad de crecimiento (VC), colouración (CM) y tipo de micelio (TM), colouración del medio(Cm), forma(F), tamaño(T) y número (N) de septos de macroconidios (Ma) y microconidios (Mi), presencia de clamidosporas (PC) y forma de clamidosporas (FC); para la caracterización patogénica se evaluó el periodo de incubación (PI), tasa de crecimiento absoluto (TCA), severidad de la enfermedad (SEV), incidencia de la enfermedad (I) y decoloración vascular (DV). Los resultados de la caracterización morfológica mostraron que todos los aislamientos corresponden a F. oxysporum. Para la variable PI, el genotipo G1 presentó el menor promedio con 18 días. En cuanto a TCA, el genotipo G2 presentó el menor incremento en altura con un valor de $0.05 \mathrm{~cm}$.día ${ }^{-1}$. Para SEV, el genotipo G1 alcanzó el nivel más alto de severidad (nivel 9) y una incidencia del 100\%. Solanum hirtum, Solanum sessiliflorum y Solanum estramonifolium fueron resistentes a los aislamientos evaluados, demostrando que existe la forma especial Fusarium oxysporum f. sp. quitoense identificada por primera vez en Nariño y se debe considerar a las especies silvestres como fuentes de resistencia para incluirse en programas de mejoramiento genético como base para la obtención de genotipos comerciales resistentes.

Palabras clave: Incidencia; Severidad; Solanum hirtum; Solanum sessiliflorum; Solanum estramonifolium.

\section{INTRODUCTION}

Lulo (Solanum quitoense Lam.) is a native shrub species of the Ecuatorian and Colombian Andes. This species produces green-fleshed fruits sought after by domestic and foreign markets due to their color, flavor, and nutritional value (Lagos et al., 2015). In Colombia, the cultivation of lulo represents $0.01 \%$ of the exported fruits' value in the country. Furthermore, lulo exports grew from 27.88t to 33.35t between 2016 and 2017 (MADR, 2019).

In recent years, there has been a reduction in the planted area, production, and yield of lulo crop in the Department of Nariño. In 2017, lulo production and yield decreased between $11.61 \%$ and $16.93 \%$, resulting in a production of 2823.5t and yield of 5.48t.ha ${ }^{-1}$ (MADR, 2019). Reduced production is due to the abandonment of the crop by farmers, mainly owing to limiting phytosanitary problems caused by Fusarium oxysporum (Lagos et al., 2015).
F. oxysporum is a soil-dwelling fungus that lives as a facultative saprophyte. Additionallly, it behaves as a pathogen that causes vascular wilt under suitable humidity conditions and temperature (López-Zapata and CastañoZapata, 2019; Hernández et al., 2020; Segura and Torres, 2020; Ochoa, 2002; RenteríaMartínez et al., 2018; Espinoza-Ahumada et al.,2019). The fungus infects the plant through the roots and colonizes the vascular system. Furthermore, during plant colonization, the pathogen also infects the seed as a means of transmission of the disease (Ochoa, 2002; Guerra-Fuentes et al., 2019; Piñeros-Guerrero et al., 2019).

Fusarium oxysporum reproduces through microconidia, macroconidia, and chlamydospores, which are responsible for the infection of new plants and dissemination throughout the crop. Particularly, chlamydospores confer resistance and remain viable in the soil for long periods of time (Nelson et al., 1994). To date, no effective control methods are known for 
affected plants; therefore, farmers are recommended to remove plants showing symptoms, leading to representative losses up to 80\% (Lagos et al., 2015).

Studies in several plant species have focused on identifying sources of resistance as an effective control method for the disease. Ribeiro et al. (2018) evaluated 41 banana accessions, identifying genotype M53 as resistant to F. oxysporum f. sp. cubense Race 1. Likewise, Carvalho et al. (2021) focused on identifying completely resistant species of passion fruit to $F$ oxysporum f. sp. passiflorae and Fusarium solani, finding that Passiflora nitida presented complete resistance to the two pathogens and can be used in breeding programs for this species.

A study in Colombia determined that wild species such as Solanum sessiliflorum, Solanum hirtum, and Solanum marginatum presented resistance to $F$. oxysporum under greenhouse conditions (Betancourth et al., 2005). The same study also evaluated the resistance of 37 genotypes of lulo de Castilla (S. quitoense) to four isolates of $F$. oxysporum collected in Nariño, finding that the genotypes evaluated presented symptoms and vascular colonization.

This research aimed to morphologically characterize different isolates of $F$. oxysporum, causing vascular wilt of lulo (VWL), from different areas of the Department of Nariño. Furthermore, the pathogenic behavior of these isolates in commercial lulo varieties and wild species of Solanum was determined.

\section{MATERIALS AND METHODS}

Location. This study was conducted at a greenhouse located in Ricaurte-Nariño $\left(1^{\circ} 11^{\prime} 17^{\prime \prime} \mathrm{N}\right.$ and $\left.77^{\circ} 58^{\prime} 25^{\prime \prime} \mathrm{W}\right)$ at an altitude of $1,230 \mathrm{~m}$ a.s.l., with temperatures ranging from 19 to $30^{\circ} \mathrm{C}$ and a relative humidity above $80 \%$ (IDEAM, 2020). Additionally, laboratory work was done at the phytopathology laboratory of the Grupo de Investigación en Producción de Frutales Andinos (GPFA), located at 2,488 $m$ a.s.l., with coordinates $1^{\circ} 14^{\prime} 3^{\prime \prime} \mathrm{N}$ and $77^{\circ} 17^{\prime} 7^{\prime \prime} \mathrm{W}$.

Collection of $F$ oxysporum isolates. Infected plant material was collected during the second semester of 2018 and the first semester of 2019 from plants with symptoms caused by $F$. oxysporum infection, such as leaf chlorosis, stem necrosis, wilting, and rotting of vascular bundles (García et al., 2007). The sampled plants were located in commercial plots, previously identified with the Municipal Agricultural Technical Assistance Units (UMATAs) of each municipality. Seventeen municipalities in the department of Nariño were sampled for a total of 20 fungal isolates collected (Table 1). 
Table 1. Passport data from 20 isolates of F oxysporum collected in 17 lulo (Solanum spp.) growing municipalities in the Department of Nariño.

\begin{tabular}{|c|c|c|c|c|c|}
\hline ISO & HOST & MUN & \multicolumn{2}{|c|}{ COORD } & ALT \\
\hline A1 & S. q Castillo & La Florida & 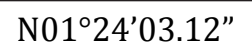 & W77²18'46.75" & 1850 \\
\hline A2 & S. $q^{*}$ S. hirtum & Arboleda & 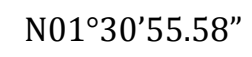 & W7708'2.57" & 2301 \\
\hline A3 & S. q Larga Vida & Arboleda & 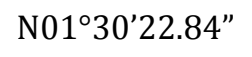 & W77 $07^{\prime} 53.57^{\prime \prime}$ & 2288 \\
\hline A4 & S. q Castillo & La Llanada & 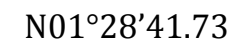 & W77³4'59.21 & 2113 \\
\hline A5 & S. q Castillo & La Unión & N013'32.5” & W7706'25.2" & 1963 \\
\hline A6 & S. q Castillo & La Unión & N0134'22.4" & $\mathrm{W} 77^{\circ} 07^{\prime} 52.0^{\prime \prime}$ & 2028 \\
\hline A7 & S. q Castillo & Consaca & 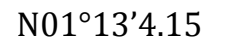 & W77² $28^{\prime} 37.03$ & 1244 \\
\hline A8 & S. q Castillo & Samaniego & N01¹9'1.17 & W77³5’36.80 & 1470 \\
\hline A9 & S. $q$ Castillo & Cartago & N013'52.2" & W7707'12.2" & 1966 \\
\hline A10 & S. $q^{*} S$. hirtum & Mallama & $\mathrm{NO1}^{\circ} 11^{\prime} 43.45$ & W7756'19.66 & 1783 \\
\hline A11 & S. q Larga Vida & Ricaurte & N01 ${ }^{\circ} 9^{\prime} 53.41$ & W77º57’49.37 & 1670 \\
\hline A12 & S. q Castillo & Tangua & N0104'25.1" & W77 $23^{\prime} 24.92^{\prime \prime}$ & 1537 \\
\hline A13 & S. q Larga Vida & Taminango & 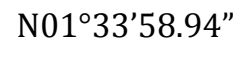 & W77 $16^{\prime} 24.86^{\prime \prime}$ & 1627 \\
\hline A14 & S. $q^{*} S$. hirtum & Ancuya & N01¹6'09.31" & W77º31'2.76" & 1359 \\
\hline A15 & S. q Castillo & Buesaco & 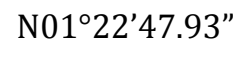 & W775ㄴ'27.0" & 2153 \\
\hline A16 & S. q Larga Vida & Buesaco & N01⒉ $22^{\prime} 10.15^{\prime \prime}$ & W7708'42.7" & 2030 \\
\hline A17 & S. $q$ Castillo & Yacuanquer & N01 $07^{\circ} 30.54^{\prime \prime}$ & W77 $26^{\prime} 26.66^{\prime \prime}$ & 2218 \\
\hline A18 & S. q Larga Vida & Colon & N0139'2.96" & W77 $02^{\prime} 23.30^{\prime \prime}$ & 2192 \\
\hline A19 & S. $q$ Castillo & EL Tambo & $\mathrm{N}^{\circ} 1^{\circ} 24^{\prime} 25.66^{\prime \prime}$ & W77 $23^{\prime} 32.71^{\prime \prime}$ & 2187 \\
\hline A20 & S. q Castillo & Linares & N01ํ2'16.18" & W77³1'31.24" & 1457 \\
\hline
\end{tabular}

ISO: isolate; MUN: municipality; COORD: coordinates; ALT: altitude in m a.s.l.; S. q: Solanum quitoense.

Pathogen isolation and purification. The collected samples were transferred to the laboratory of phytopathology of Universidad de Nariño. The plant material was washed with sterile distilled water, then, $5 \mathrm{~mm}$ sections of healthy and diseased tissue were cut from stems and branches. The tissues were disinfected with distilled water and $2.5 \%$ sodium hypochlorite $(\mathrm{NaClO})$ for 1 minute and $70 \%$ alcohol for 1 minute. Finally, they were washed with sterile distilled water, then, four cuttings per Petri dish were seeded on Potato Dextrose Agar (PDA) medium and incubated at $28^{\circ} \mathrm{C}$ for 48 hours. Once fungal structures were obtained, fungal replication was performed until pure cultures of 20 isolated colonies of the pathogen were obtained (Nelson et al., 1994).

Monosporic cultures. To obtain pure cultures from a single spore, a low concentration suspension of conidia in sterile water was made from pure cultures on PDA medium. For this, the mycelium in the Petri dishes was washed with sterile water, $0.5 \mathrm{ml}$ of the suspension was taken, the contents were added to a water-agar medium and streaked with a sterile glass rod. Germination of the conidia was observed under a stereoscope at time intervals of 24, 48 and 72 hours. Once germination started, conidia with isolated growth were observed. A section of the agar 
was extracted using a sterile needle, then, a conidium was transferred to Petri dishes with PDA medium to obtain 10 replicates of pure cultures from each isolate (Nelson et al., 1994).

\section{Morphological identification of $\boldsymbol{F}$.} oxysporum. Morphological identification of the pure cultures was done using the taxonomic keys developed by Nelson et al. (1994) and Leslie and Summerell (2006). Macroscopic morphological characteristics were determined from eight-day-old fungal colonies by observing the texture, color, and PDA medium growth. On the other hand, microscopic parameters of shape, size, chlamydospores (e.g., shape, presence, size), and number of macroconidia and microconidia septa were determined from pure mycelia grown on Carnation Leaf Agar (CLA) medium with lactophenol staining, observed under light microscopy.

\section{Pathogenicity test}

Plant material. The lulo plants were obtained from seeds of visually healthy plants in seven lulo growing municipalities in the Department of Nariño, namely La Florida, Arboleda, Mallama, La Union, Ancuya, Buesaco, and El Tambo, located at altitudes ranging from 1,320 to 2,301 m a.s.l. Wild plant material of $S$. hirtum, S. sessiliflorum and $S$. stramonifolium were obtained from spontaneously growing plants in the municipalities of MocoaPutumayo (590 m a.s.l.) and Tumaco (764 m. a.s.l.). A total of 100 seeds of each genotype were sown in order to select five plants of homogeneous growth for inoculation. A total of 500 plants were evaluated under greenhouse conditions.
Inoculation of seedlings with $\boldsymbol{F}$. oxysporum. The inoculum was obtained from a mycelial wash with sterile distilled water at a concentration of $1 \times 10^{6}$ spores.ml $^{-1}$ of the purified fungus and calibrated in a Neubauer chamber. Subsequently, five seedlings (two months old with two true leaf pairs) per material were inoculated by injecting $3 \mathrm{ml}$ of the suspension at the base of the stem, according to the methodology of Cardona and Castaño (2019). Additionally, distilled water was injected as a negative control. Once the plants were inoculated, they were kept at field capacity for 15 days to facilitate the development of the disease (Betancourth et al., 2005).

\section{Traits assessed}

Morphological characterization. Observations of morphological structures were done at $40 \mathrm{X}$ and $100 \mathrm{X}$ magnification for detailed microconidia, macroconidia, and chlamydospore structures. The characterization was based on the descriptions of Nelson et al. (1994) and Leslie and Summerell (2006), considering the following variables: i) Growth rate of colonies in the PDA culture medium, estimated as the ratio between the diameter of the colonies (mm) and the time required to colonize the total Petri dish area (mm.day $\left.{ }^{1}\right)$. ii) Mycelium color and type according to the Auction Color Chart $\AA$ (2004). iii) Growth medium color according to the Auction Color Chart $\AA^{2}$ (2004). iv) shape and size of macroconidia and microconidia in $\mu \mathrm{m}$. v) Number of macroconidia and microconidia septa (1-6 septa). vi) Chlamydospore presence and shape.

Pathogenicity characterization. The pathogenicity test was conducted for 98 days and variables were measured every seven days. Disease incubation period was 
determined as the number of days to symptom onset after inoculation (IP); additionally, absolute growth rate (AGR) was recorded as

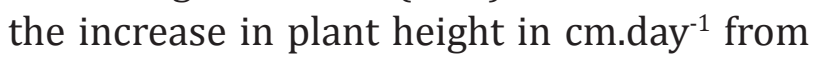
the time of inoculation and calculated using the formula:

$$
A P=\frac{A P 2-A P 1}{T 2-T 1}
$$

Where: $\mathrm{AP} 1=$ plant height at time $1, \mathrm{AP} 2=$ plant height at time 2 , T2 = evaluation time 2 and $\mathrm{T} 1=$ evaluation time 1 .

Disease severity (DS) was expressed as a percentage (\%) using the scale proposed by Estupiñan and Ossa (2007) (Table 2).

Table 2. Disease severity scale for Fusarium oxysporum.

\begin{tabular}{ccl}
\hline Severity & Percentage & \multicolumn{1}{c}{ Characteristics } \\
\hline 1 & 0 & $\begin{array}{l}\text { No symptom } \\
\text { manifestation } \\
\text { No more than } 10 \% \text { of } \\
\text { the total foliage is wilted } \\
\text { and/or chlorotic } \\
3\end{array}$ \\
& 10 & $\begin{array}{l}\text { Leaves wilted or } \\
\text { chlorotic } \\
\text { Leaves wilted or } \\
\text { chlorotic } \\
\text { Dead or severely } \\
\text { infected plants showing } \\
\text { virtually all foliage } \\
\text { with wilted, chlorotic, } \\
\text { necrotic, and/or } \\
\text { premature defoliation }\end{array}$ \\
\hline
\end{tabular}

Vascular discoloration (VD) was determined through a transverse cut in the stem of each plant at the end of the evaluation period. VD was described according to the scale of Estupiñan and Ossa (2007), as shown in Table 3.
Table 3. Vascular discoloration scale according to Estupiñan and Ossa (2007).

\begin{tabular}{|c|c|c|}
\hline VD & DS & CHARACTERISTIC \\
\hline 0 & NONE & \\
\hline 1 & SLIGHT & \\
\hline 2 & INTERMEDIATE & \\
\hline 3 & SEVERE & \\
\hline
\end{tabular}

Resistance (-) or incompatibility reactions were indicated by levels 0 and 1 of vascular discoloration (i.e., no evidence of damage and none or slight discoloration of the vascular system). Conversely, susceptibility (+) or compatibility reactions were manifested by levels 2 and 3 (i.e., intermediate vascular discoloration in a large part of the plant and severe vascular discoloration of the whole plant, respectively) (CIAT, 2010).

Reisolation of the fungus. Sections of vessels were taken from the base of stems with and without symptoms after the evaluation period. The sections were placed on PDA and incubated at $22^{\circ} \mathrm{C}$ for eight days to test Koch's postulates (Estupiñan and Ossa, 2007).

Experimental design. A completely randomized design was used with three replicates per isolate and a control isolate. The design considered two factors: the first factor corresponded to 20 isolates of $F$. oxysporum and the second factor to 10 genotypes of lulo, in addition to the control inoculated with distilled water. The experimental unit consisted of one seedling planted in a bag with a capacity of $1 \mathrm{Kg}$ of sterile substrate under greenhouse conditions.

Statistical analysis. The observed pathogenicity data were subjected to an Analysis of Variance (ANOVA) using S.A.S. software version 9.4 (Statistical Analysis 
System, Institute Inc.). Significant differences were established when the hypothesis test allowed rejecting the null hypothesis, i.e., significant or highly significant statistical differences were determined when the means of the genotypes exceeded the general mean plus one standard error $(\mu+\sigma)$ or twice the standard error $(\mu+2 \sigma)$, respectively, according to Lagos et al. (2015). For the traits related to pathogenicity and aggressiveness of $F$. oxysporum, the most outstanding genetic materials were those below $\mu-\sigma$ or $\mu-2 \sigma$, with significant or highly significant differences compared with the others.

\section{RESULTS AND DISCUSSION}

Collection of isolates. A total of 17 municipalities with established lulo crops were sampled in the Department of Nariño. The municipalities were located at elevations ranging from 1,244 to $2,301 \mathrm{~m}$ a.s.l. and average temperatures between 20 and $23^{\circ} \mathrm{C}$. The selected areas presented visually diseased plants with typical symptoms such as foliage wilting, dwarf plants, chlorosis in the lower leaves, and vascular tissue with orange-brown colorations observed by a longitudinal section of the stem (Figure 1). These characteristics agree with the description of Forero-Reyes et al. (2018), who report that pathogen hyphae growth throughout the xylem allows the colonization and obstruction of the ducts, generating an observable necrosis through longitudinal sections of the stem.

Morphological characterization of $F$. oxysporum. The macroscopic morphological identification of the 20 isolates showed colony (GR) growth rates ranging from 7 to 21 days. For mycelium color, type, and medium color, different shades ranging from whitishpink, purplish-white to intense purple and intense pink were observed. These results are similar to those obtained by Nelson et al. (1994), Betancourth et al. (2005), Leslie and Summerell (2006), Robles-Carrión et al. (2016), Arellano (2018), Leyva-Mir et al. (2018), Retana et al. (2018), who state that these mycelial colors are a characteristic feature of $F$. oxysporum since it displays great color variation on PDA medium.

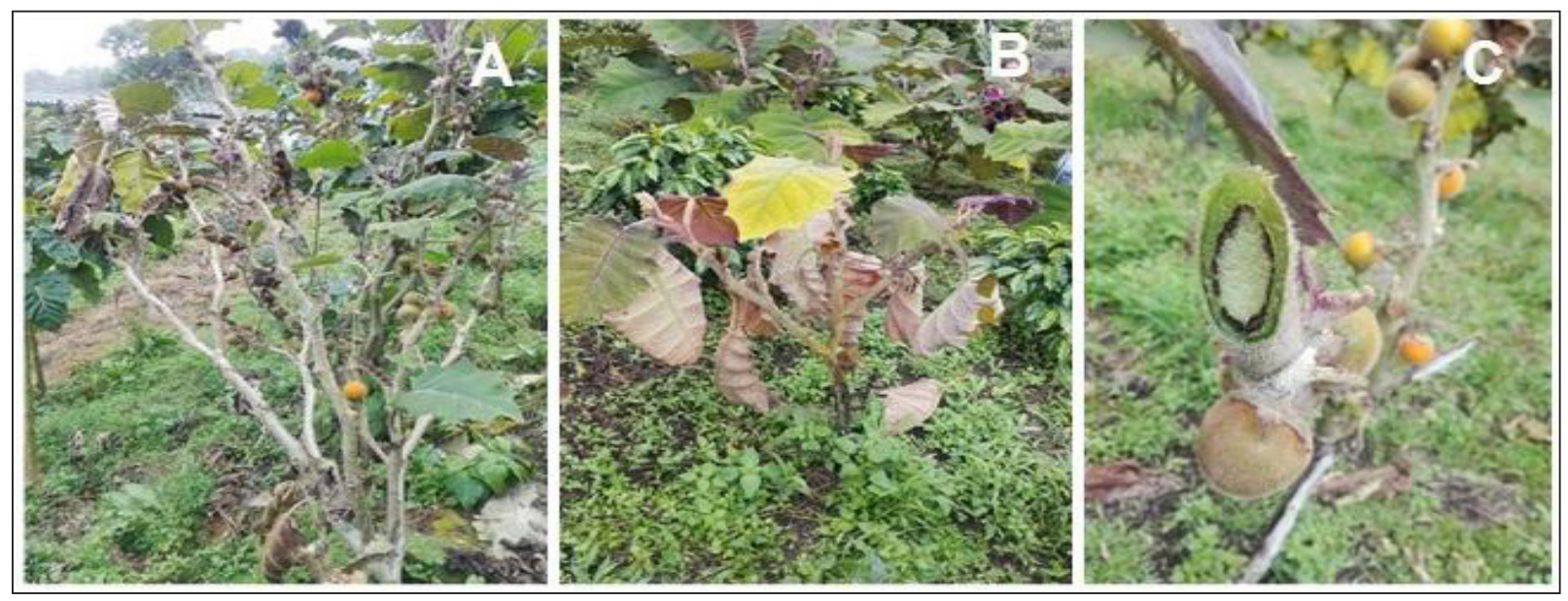

Figure 1. Symptoms observed in the field in different municipalities of the Department of Nariño. A) Foliage wilt B) Dwarf and chlorotic plants C) Necrotic vascular tissue with brown coloring. 
The mycelium of the different isolates varied from very sparse to dense, with irregular to continuous shapes, and aerial or flattened growth. These observations are similar to those described by Castro et al. (2018), who evaluated eight strains of $F$. oxysporum on PDA medium, isolated from cultures of $S$. quitoense in Pastaza, Ecuador. The authors found variable results regarding mycelial color (purple and white), with irregular shape, slow growth, cottony appearance, sparse, purple in the center and white on the edges, both on the back and the reverse.

The observations of the different isolates on CLA medium after 12 days of germination indicated the presence of unicellular, ovoid, and oval microconidia with one and two cells in single or short chains. Additionally, macroconidia were hyaline, slender (i.e., almost needle-shaped), multiseptated (3 to 6 septa), with a hooked apex for isolates A1, A2, A4, A5, A6, A6, A9, A11, A12, A13, A14, A15, A16, A17, A18, A19 and blunt apex for isolates A3, A7, A8, A10, A20. Foot cells were minutely notched, clear notches were observed only for A18, and thick-walled, globose, unicellular, hyaline chlamydospores were present in chains or clusters.

These macroscopic observations allowed identifying the isolates as F. oxysporum and corroborated findings from previous studies (Nelson et al., 1994; Leslie and Summerell, 2006; Iturbide-Zuñiga et al., 2017; MariscalAmaro et al., 2017; Buitrago, 2018; Huarhua, 2018; López et al., 2018). These investigations reported that the pathogen produces three types of asexual spores: microconidia formed by one or two cells, macroconidia (spores) with three to five cells that gradually slim down and curl towards both ends, and chlamydospores constituted by one or two cells, which are thick-walled and classified as survival structures.

Finally, 20 isolates with microscopic morphological characteristics similar to F. oxysporum were obtained on CLA medium (Figure 2). Observations of these structures allowed identifying microconidia, macroconidia, and chlamydospores.

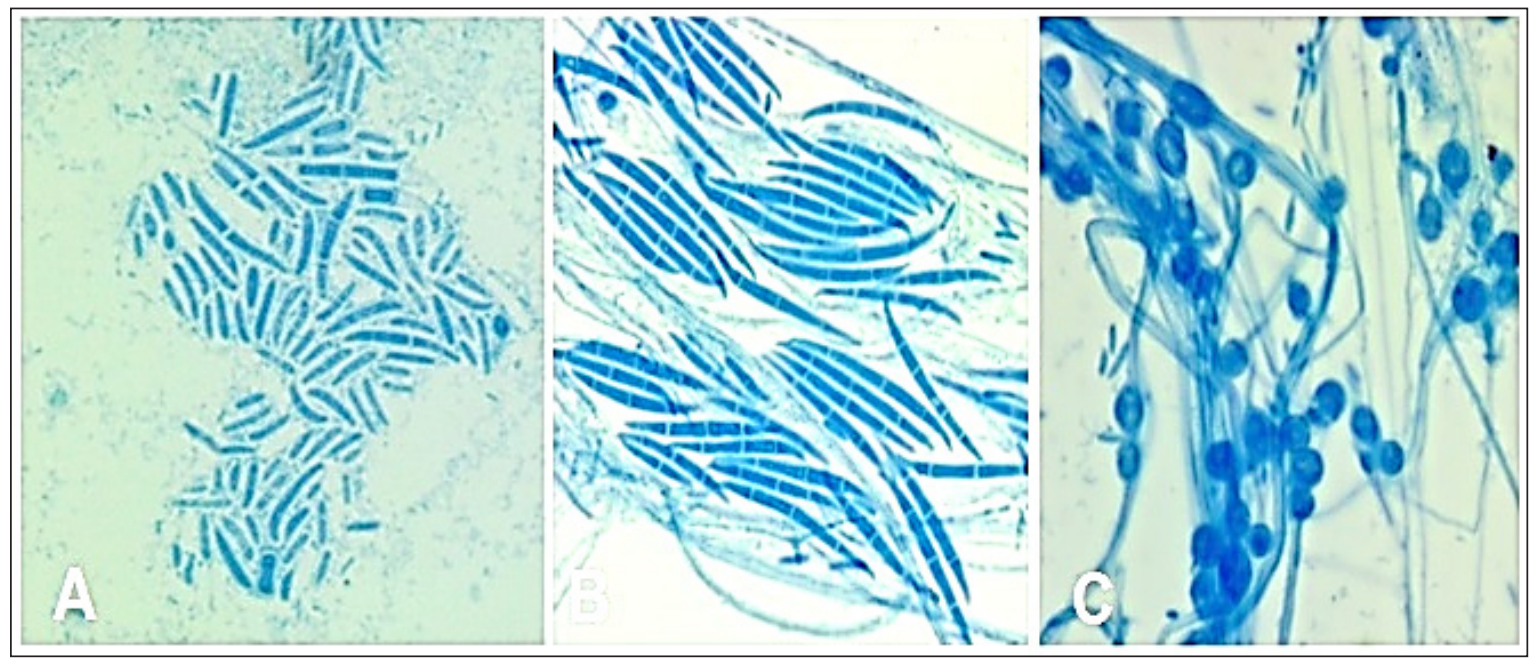

Figure 2. Structures of the fungus Fusarium oxysporum observed under the light microscope. $\mathrm{A}$ and B: macroconidia, C: chlamydospores. 
Pathogenic characterization of $F$ oxysporum. According to the ANOVA (Table 4), significant differences were found for all the traits related to the pathogenesis of the isolates. The isolates showed highly significant differences in response to the interaction with the genotype, indicating that they behaved differentially across the different lulo genotypes evaluated in this study.

Table 4. Mean squares of the ANOVA for incubation period (IP), absolute growth rate (AGR), and disease severity (DS) evaluated in seven genotypes of lulo and three wild plant materials inoculated with 20 isolates of $F$. oxysporum.

\begin{tabular}{ccccc}
\hline VF & DF & IP & AGR & DS \\
\hline Repetition & 3 & $438.42 \mathrm{~ns}$ & $0.0076 \mathrm{~ns}$ & $1908.77 \mathrm{~ns}$ \\
Isolate (Is) & 21 & $1076.01^{*}$ & $0.042^{* *}$ & $2012.28^{*}$ \\
Genotype (G) & 10 & $7535.03^{* *}$ & $0.66^{* *}$ & $13793.32^{* *}$ \\
IsxG & 21 & $651.12^{* *}$ & $0.014^{* *}$ & $1155.51^{* *}$ \\
Error & 418 & 247.71 & 0.0061 & 574.65 \\
\hline CV & & 160.39 & 31.09 & 186.03 \\
$\mathrm{R}^{2}$ & & 0.67 & 0.78 & 0.61 \\
Average & & 27.89 & 0.25 & 12.71 \\
SD & & 13.24 & 0.07 & 22.72 \\
\hline
\end{tabular}

$*=$ significant at $P<0.05 ; \mathrm{C} . \mathrm{V}=$ coefficient of variation; $\mathrm{R}^{2}=$ coefficient of determination; $\mathrm{SD}=$ standard deviation.

Incubation period (IP). Genotypes G9, G8, and G6 showed the shortest time of symptom onset (15 - 16 days) and presented chlorosis on the lower leaves. Next, G5, G2 and G3 presented symptoms after 18 to 19 days and, finally, G1 presented the highest average time of symptom onset on day 22 (Table 5).

These results differ from findings by Duarte-Alvarado et al. (2020), who reported incubation periods of seven days on $S$. quitoense plants inoculated with nine $F$. oxysporum isolates obtained from lulo plants in Nariño. Furthermore, Ochoa et al. (2001) found incubation periods of 39 to 48 days with an inoculum concentration of $5 \times 10^{6}$ conidia.ml ${ }^{-1}$. This large difference in disease incubation period can be explained due to the inoculation method used by Ochoa et al. (2001), which consisted of generating wounds in the root for pathogen entry. It can also be attributed to differences in the infective capacity of the isolates and the resistance or susceptibility of the materials. This pathogen can present different rates of host colonization, depending on the time of initial infection, virulence, and climatic conditions (Gonzales et al., 2012). 
Table 5. Mean incubation period (IP), absolute growth rate (AGR), and disease severity (DS) in 10 genotypes of lulo (Solanum quitoense Lam.) inoculated with Fusarium oxysporum.

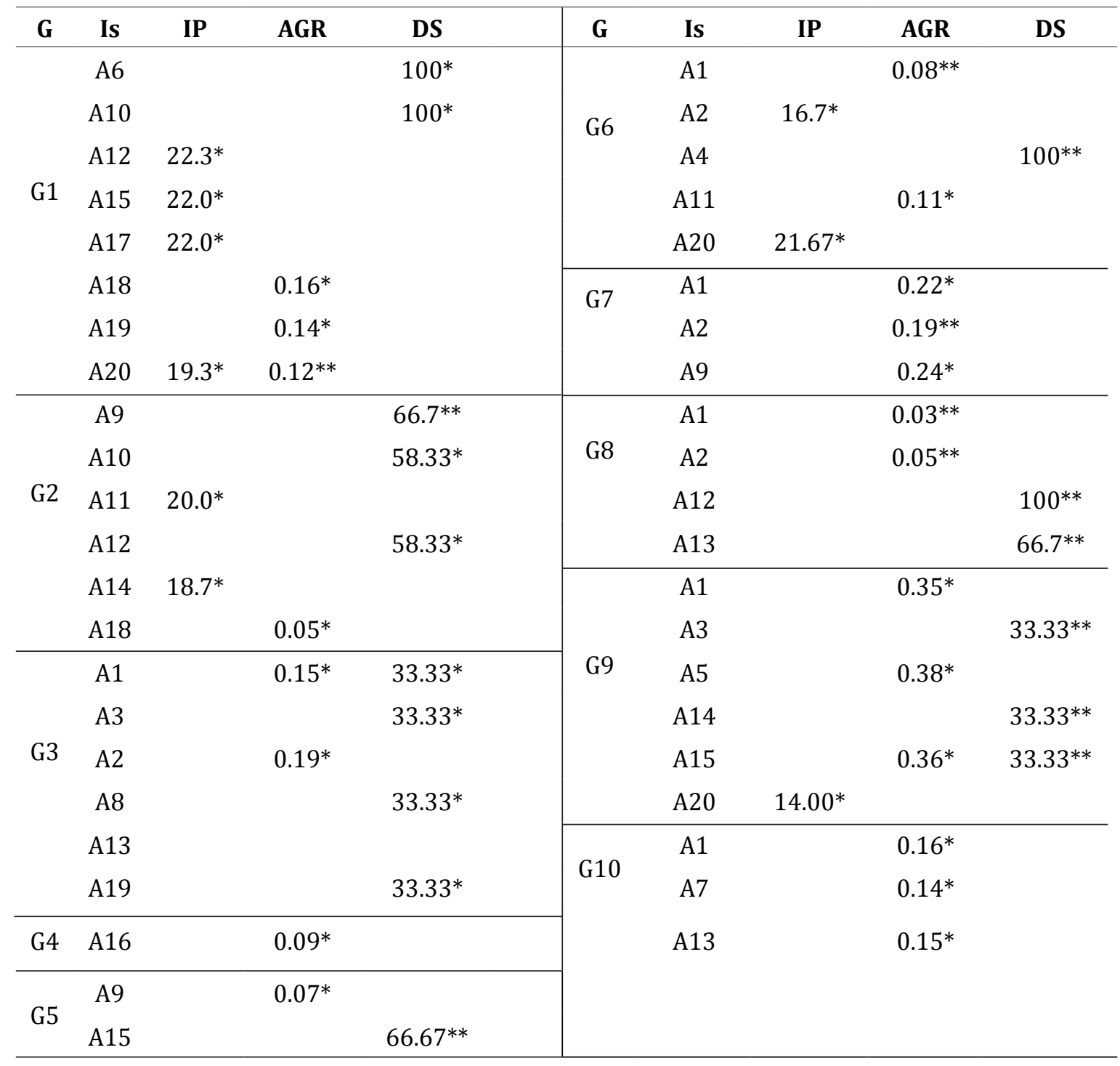

* = significant at $P<0.05$; ** $=$ significant at $P<0.01$.

Genotypes G4, G7, and G10, belonging to the wild materials of $S$. hirtum, $S$. sessiliflorum and $S$. stramonifolium, did not present any symptoms during the experiment so there were no values registered for pathogenicity traits. These findings agree with reports by Betancourth et al. (2005) regarding S. hirtum and $S$. sessiliflorum as sources of resistance to F. oxysporum. Moreover, given the selectivity of the isolates towards generating infection processes in Solanum quitoense, it is possible to affirm that there is a special form of the fungus identified as $F$. oxysporum f. sp. quitoense, which has been reported by Ochoa et al. (2001) and Avila et al. (2019) in Ecuador.

Absolute growth rate (AGR). Table 5 shows the significant means of the AGR for each genotype, indicating the adverse effect that the isolates generate on normal plant 
development. In G1, significant means were obtained with isolates A18 (0.16 cm.day $\left.{ }^{-1}\right)$ and A19 $\left(0.14 \mathrm{~cm}^{\left.-d_{a y}{ }^{-1}\right)}\right.$, and highly significant with A20 (0.12 cm.day ${ }^{-1}$ ). Particularly, the mean for this genotype ranged from 0.12 to $0.33 \mathrm{~cm}$ day $^{-1}$.

For G2, only isolate A18 showed a significant

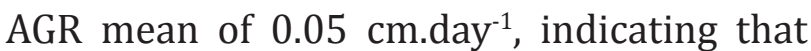
the isolate's infective capacity generates a physiological imbalance in this genotype that limits normal apical growth. In G3, isolate A1 stands out with an AGR of 0.15 cm.day $^{-1}$,

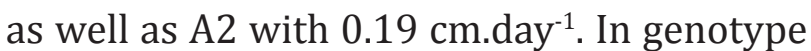
G4, isolate A16 showed a significant mean of $0.09 \mathrm{~cm}^{- \text {day }^{-1}}$. The AGR in genotype G4 ranged from 0.09 to $0.337 \mathrm{~cm}_{\text {day }}{ }^{-1}$. Similarly, in G5, only isolate A9 showed a significant mean of $0.07 \mathrm{~cm}$ day $^{-1}$. In G6, isolate A1 presented a highly significant mean of $0.083 \mathrm{~cm}^{-d_{a y}{ }^{-1} \text { and }}$ A11 displayed a significant mean of 0.113

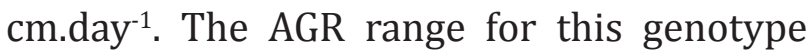
was 0.083 to $0.33 \mathrm{~cm}^{-d_{a y}{ }^{-1}}$ (Table 5).

For G7, isolates A1 and A9 reported significant means and A2 a highly significant mean. Specifically, A2 showed the smallest increase relative to the overall mean of $0.19 \mathrm{~cm}_{\text {.day }}{ }^{-1}$. Similarly, G9 showed significant means for isolates A1, A5, and A15, $(0.35,0.38$, and 0.36 $\mathrm{cm}$ day $^{-1}$, respectively). Finally, in G10, isolates A1, A7, and A13 demonstrated significant means; particularly, A7 showed the smallest increase compared to the overall mean of 0.2 cm.day ${ }^{-1}$.

Accordingly, isolates A1, A2, A9 and A18 displayed a high infective capacity (Table 4). According to Gonzales (2012), F. oxysporum produces phytotoxins that cause a growthinhibitory reaction by hormonal imbalance since these substances are strong enough to overcome the growth-stimulating action of gibberellins. In addition, plants affected by this pathogen usually express a type of dwarfism compared to healthy plants.

On the other hand, reduced seedling growth is due to the successful development of the pathogen in the genotypes. According to Ángel-García et al. (2018), the pathogen enters the plant directly, or through wounds, and spreads through the xylem vessels. Subsequently, the mycelium invades the vascular tissue and conidia, thus, physically blocking these vessels and preventing the transport of water and nutrients. Consequently, the plant metabolism is altered, causing cellular processes to be reduced or stopped.

Disease severity (DS). In G1, isolates A6 and A10 reached the highest severity (level 9), indicated by total foliage wilting, generalized chlorosis, tissue necrosis, and premature defoliation by the end of the evaluation. Thus, these isolates showed significant means.

In $\mathrm{G} 2$, isolate $\mathrm{A} 9$ generated a severity of $66.7 \%$, followed by A10 and A12 with 58.33\% severity. In G3, the severity levels ranged from 5 to 7 with isolates A1, A3, A8, A13, and A19 (33.33\%), which induced wilted or chlorotic leaves during the 14 weeks of evaluation.

Likewise, in G5, isolate A15 showed a highly significant mean and induced level 7 disease severity (66.67\%), indicated by wilted or chlorotic leaves between weeks 11 and 13, respectively. In this same genotype, A3, A4, $A 8, A 9, A 10$, and $A 11$ induced disease severity levels between 1 and 5, with no more than $10 \%$ of the total foliage wilted or chlorotic.

Moreover, G6 showed a highly significant mean with isolate A4, reaching level 9 severity after 
12 weeks of inoculation. Therefore, $100 \%$ of the plants were severely affected, indicated by total foliage wilting, general chlorosis, necrosis, and premature defoliation.

In G8, A12 and A13 generated highly significant means (100\% and $66.7 \%$, respectively), reaching level 9 severity by week 10. Finally, in G9, isolates A3, A14, and A15 generated significant values, reaching low severity levels between 3 and 5 (33.33\%), demonstrated by wilted and chlorotic leaves (Table 5).

These results agree with those reported by Betancourth et al. (2005), who mention that, after 12 weeks, the disease was more aggressive, inducing general wilting of the leaves and 100\% seedling death (level 9 severity).
Genotypes G4, G7, and G10, belonging to the wild materials of $S$. hirtum, $S$. sessiliflorum, and $S$. stramonifolium, did not show any symptoms during the experiment so no values were registered for the pathogenicity variables. These findings confirm the selectivity of the isolates towards $F$. oxysporum f. sp. quitoense.

Disease incidence (I). The disease incidence of the isolates on the genotypes evaluated is shown in Table 6. The results are presented according to the isolates' individual effect and theirpathogenicdifferences. Thesedifferences may be attributed to variations in the macroscopic morphological characteristics, which sometimes generate alterations in their infective capacity (Betancourth et al., 2005).

Table 6. Disease incidence (\%) assessed in genotypes of lulo (Solanum spp.)

\begin{tabular}{cccccccc}
\hline Isolate & G1 & G2 & G3 & G5 & G6 & G8 & G9 \\
\hline A1 & 66.7 & 0 & 66.7 & 66.7 & 66.7 & 0 & 0 \\
A2 & 100 & 33.3 & 0 & 0 & 33.3 & 0 & 0 \\
A3 & 100 & 0 & 100 & 33.3 & 0 & 33.3 & 33.3 \\
A4 & 100 & 0 & 0 & 33.3 & 100 & 33.3 & 0 \\
A5 & 100 & 0 & 0 & 0 & 66.7 & 0 & 0 \\
A6 & 100 & 0 & 0 & 0 & 0 & 0 & 0 \\
A7 & 100 & 0 & 33.3 & 0 & 100 & 0 & 0 \\
A8 & 100 & 0 & 33.3 & 33.3 & 66.7 & 0 & 0 \\
A9 & 66.7 & 66.7 & 0 & 33.3 & 0 & 0 & 0 \\
A10 & 100 & 100 & 0 & 33.3 & 0 & 0 & 0 \\
A11 & 33.3 & 33.3 & 0 & 33.3 & 33.3 & 0 & 0 \\
A12 & 33.3 & 100 & 0 & 33.3 & 0 & 100 & 0 \\
A13 & 66.7 & 100 & 33.3 & 33.3 & 0 & 66.7 & 0 \\
A14 & 66.7 & 33.3 & 0 & 33.3 & 0 & 33.3 & 33.3 \\
A15 & 66.7 & 0 & 0 & 66.7 & 100 & 0 & 33.3 \\
A16 & 0 & 0 & 0 & 0 & 0 & 0 & 0 \\
A17 & 33.3 & 0 & 0 & 0 & 0 & 0 & 0 \\
A18 & 0 & 0 & 0 & 0 & 0 & 0 & 0 \\
A19 & 0 & 0 & 33.3 & 33.3 & 0 & 0 & 0 \\
A20 & 33.3 & 0 & 0 & 33.3 & 33.3 & 0 & 33.3 \\
TEST & 0 & 0 & 0 & 0 & 0 & 0 & 0 \\
\hline
\end{tabular}


For G1, isolates A2, A3, A4, A5, A6, A7, A8, and A10 showed a disease incidence of $100 \%$ at 14 weeks. Additionally, isolates A1, A9, A13, $\mathrm{A} 14$, and A15 demonstrated an incidence of $66.6 \%$ by the end of the experiment. Similarly, A11, A12, A17, and A20 affected 33.3\% of plants, which displayed chlorosis in the lower leaves and loss of turgor. Conversely, isolates A16, A18 and A19 did not showed disease incidence in this genotype.

In $\mathrm{G} 2$, isolates $\mathrm{A} 10, \mathrm{~A} 12$, and $\mathrm{A} 13$ showed $100 \%$ incidence by the end of the evaluation. Furthermore, A9 displayed $66.6 \%$ incidence, while A2, A11, and A14 caused disease in $33.3 \%$ of the plants. The remaining isolates did not affect any plants. In G3, the highest incidence was obtained by A3 (100\%). Isolate $\mathrm{A} 1$ showed $66.6 \%$ incidence, while $\mathrm{A} 7$, A8, A13, and A19 displayed 33.3\% disease incidence.

The highest disease incidence in G5 was obtained by isolates A1 and A15 (66.6\%). Moreover, in G6, $100 \%$ of the plants were affected by isolates A4, A7, and A15; additionally, $66.6 \%$ were affected by isolates A1, A5 and A8. The highest incidences in G8 were caused by isolates A12 and A13 (100\% and $66.6 \%$, respectively), while the lowest incidence was obtained by A3, A4 and A14 (33.3\%).

These results differ from those reported by Arizala et al. (2011), who evaluated the reactions of wild Solanaceae to the effect of $F$. oxysporum, finding that $S$. hirtum showed the lowest disease incidence (5.55\%) and $S$. quitoense showed the most affected plants (25\% incidence). Moreover, the mean values obtained here are low compared to the findings by Maya and Lagos (2011), who report an incidence of $92.57 \%$ in half-sibling families of lulo.
The control isolates (TEST) did not show any symptoms during the 14 weeks of evaluation; thus, their development was normal and they were not affected by the fungus (Table 6).

Vascular discoloration (VD). Different levels ofVDwereobservedintheinoculated seedlings by the end of the $14^{\text {th }}$ week of evaluation. The results allowed demonstrating the resistance or susceptibility of each genotype to the attack by the different isolates (Table 7).

In $\mathrm{G} 1$, isolates $\mathrm{A} 11, \mathrm{~A} 12, \mathrm{~A} 16, \mathrm{~A} 17$, and $\mathrm{A} 19$ generated level $1 \mathrm{VD}$, which consisted of slight or light pigmentation of the vascular bundles due to the development of the pathogen inside the plant. The remaining isolates induced level $3 \mathrm{VD}$, observed by a dark brown coloring (severe) in the stem tissues, indicating the destruction and total colonization of the conductive tissues of the plant due to the development and proliferation of the pathogen.

G2 showed susceptibility to isolates A9, A10, A11, A12, A13, A14, and A20, observed by VD levels of 2 to 3 . Conversely, the remaining isolates did not generate VD for this genotype. Similarly, in G3, the compatible isolates were A1, A8, A9, A12, A13, A17, A19, and A20, which induced VD of 2 to 3 . The other isolates showed incompatibility with this genotype. G4, corresponding to $S$. hirtum, only showed susceptibility to A18, indicated by level 2 VD. Accordingly, intermediate coloring and tissue colonization was observed for G4; however, the plants survived the experiment. This genotype shows resistance to the other isolates; therefore, it can be considered a source of resistance and be included in crossbreeding schemes to obtain resistant hybrids with agronomic potential. 
Table 7. Vascular discoloration (VD) of lulo (Solanum spp.) seedlings caused by 20 isolates of $F$. oxysporum.

\begin{tabular}{ccccccccccc}
\hline Isolate & G1 & G2 & G3 & G4 & G5 & G6 & G7 & G8 & G9 & G10 \\
\hline A1 & 3 & 0 & 3 & 0 & 3 & 3 & 1 & 1 & 0 & 1 \\
A2 & 3 & 0 & 0 & 0 & 0 & 3 & 0 & 1 & 1 & 0 \\
A3 & 3 & 0 & 1 & 1 & 3 & 0 & 1 & 1 & 3 & 0 \\
A4 & 3 & 0 & 1 & 0 & 3 & 3 & 1 & 3 & 1 & 0 \\
A5 & 3 & 0 & 0 & 0 & 0 & 2 & 1 & 1 & 0 & 0 \\
A6 & 3 & 0 & 0 & 0 & 1 & 0 & 1 & 0 & 0 & 0 \\
A7 & 3 & 0 & 1 & 0 & 0 & 1 & 1 & 1 & 0 & 0 \\
A8 & 3 & 0 & 3 & 0 & 0 & 2 & 1 & 2 & 0 & 0 \\
A9 & 3 & 3 & 2 & 0 & 3 & 0 & 1 & 1 & 0 & 0 \\
A10 & 3 & 3 & 0 & 0 & 1 & 0 & 2 & 1 & 1 & 0 \\
A11 & 1 & 2 & 0 & 0 & 3 & 3 & 0 & 0 & 1 & 0 \\
A12 & 2 & 3 & 2 & 1 & 1 & 3 & 1 & 3 & 0 & 0 \\
A13 & 3 & 3 & 3 & 0 & 3 & 3 & 3 & 3 & 0 & 0 \\
A14 & 3 & 3 & 0 & 1 & 3 & 0 & 2 & 3 & 0 & 0 \\
A15 & 3 & 0 & 1 & 0 & 3 & 1 & 0 & 2 & 0 & 0 \\
A16 & 1 & 0 & 0 & 1 & 0 & 3 & 2 & 0 & 0 & 0 \\
A17 & 1 & 0 & 2 & 0 & 0 & 2 & 1 & 0 & 3 & 0 \\
A18 & 3 & 0 & 0 & 2 & 0 & 2 & 0 & 0 & 0 & 0 \\
A19 & 0 & 0 & 3 & 0 & 1 & 1 & 1 & 0 & 0 & 0 \\
A20 & 3 & 2 & 2 & 0 & 1 & 3 & 2 & 3 & 1 & 0 \\
TEST & 0 & 0 & 0 & 0 & 0 & 0 & 0 & 0 & 0 & 0 \\
\hline & & & & & & & & & & 0
\end{tabular}

Genotype G5 showed compatibility with isolates $\mathrm{A} 1, \mathrm{~A} 3, \mathrm{~A} 4, \mathrm{~A} 9, \mathrm{~A} 9, \mathrm{~A} 11, \mathrm{~A} 13, \mathrm{~A} 14$, and $\mathrm{A} 15$ (level $3 \mathrm{VD}$ ), while the other isolates showed incompatibility. Moreover, G6 showed susceptibility to A1, A2, A4, A5, A8, A11, A12, A13, A16, A17, A18, and A20 (levels 2 and 3 of VD), and the remaining isolates were incompatible.

G7, corresponding to $S$. stramonifolium, showed a compatibility reaction with $\mathrm{A} 4$, A8, A12, A13, A14, A15, and A20, displayed by levels 2 and 3 of VD. However, the plants showed mild symptoms during the experiment and presented an incompatibility reaction with the other isolates. Additionally, G8 showed compatibility with A4, A8, A12, A13, A14, A15, and A20, indicated by levels 2 and 3 of VD, while G9 only demonstrated susceptibility to A3 and A17 (level 3 VD). Finally, G10, corresponding to $S$. sessiliflorum, did not show susceptibility to any of the isolates, demonstrating complete resistance to the pathogen. Therefore, this material 
can be considered a wild species with genes of interest in breeding programs to obtain resistant genotypes with desirable agronomic potential.

Overall, these results allowed establishing that G1 was the most susceptible with 17 compatibility reactions with the isolates, followed by G5 with 12, G6 with nine, G2 with seven, G3 with six, G8 with five, and G9 with four reactions. These differences in the compatibility of the genotypes with certain isolates are due to genetic factors that activate a series of defense mechanisms to inhibit, slow, or counteract the infection, which, in some cases, are insufficient to avoid the infectious process. Furthermore, the fungus is highly variable and can present differences in its vascular colonization capacity in different lulo materials (Forero et al., 2015).

Gabriel et al. (2020) mention that resistance mechanisms can be structural, such as the production of waxes, cuticles, hairy structures, among others. Additionally, they can be biochemical, constituted by enzymatic changes or the production of phenolic compounds or tannins. Lastly, these mechanisms can be induced, for instance, by the synthesis of phytoalexins, in response to different types of aggression. These modes of resistance may be effective in the wild genotypes of $S$. hirtum, S. sessiliflorum, and $S$. stramonifolium evaluated in this study, which are resistant to F. oxysporum f. sp. quitoense.

The results of this study showed that all isolates of $F$. oxysporum f. sp. quitoense were pathogenic to Solanum quitoense. This agrees with reports by Manangon et al. (2015), who found vascular colonization level 3 in several accessions of Castilla lulo, highlighting that fungal isolate 12 from the hybrid Puyo did not affect three accessions. However, the authors mention that all $S$. quitoense accessions were susceptible and one accession of $S$. sessiliflorum showed susceptibility to one of the isolates.

On the other hand, Gallardo (2005) observed that $S$. sessiliflorum and $S$. hirtum expressed VD in response to $F$. oxysporum, contrasting with the results found in this study; however, these differences may be due to a new special form of fungus that affected these two wild species.

\section{CONCLUSIONS}

The isolates obtained from different lulo cultivars showed differences in colony color, mycelium type, and mycelial growth. However, they did not show structural differences observed under light microscopy and corresponded to $F$. oxysporum f. sp. quitoense.

The isolates behaved differentially across the lulo genotypes studied and displayed pathogenic differences. Disease severities of $100 \%$ were determined for isolates A6 and $\mathrm{A} 10$ in G1, A4 in G6, and A12 in G8.

Wild plant materials of $S$. hirtum, $S$. sessiliflorum, and $S$. stramonifolium were resistant to $F$. oxysporum f. sp. quitoense, while $S$. quitoense materials were susceptible to attack by this special fungal form.

Conflict of interests: The authors declare that there is no conflict of interest.

\section{REFERENCIAS BIBLIOGRÁFICAS}

Ángel-García, C.; Robledo-Buritica, J.; CastañoZapata, J. (2018). Comparación de métodos de inoculación de Fusarium solani f. sp. passiflorae 
en plántulas de maracuyá (Passiflora edulis f. flavicarpa). Revista U.D.C.A Actualidad \& Divulgación Científica. 21 (1): 23-31. doi:10.31910/rudca.v21.n1.2018.659

Arellano, M. (2018). Detección de Fusarium oxysporum en cultivos de uvilla (Physalis peruviana L.) en la Sierra norte y centro del Ecuador. Retrieved from http://repositorio.puce. edu.ec/handle/22000/14683.

Arizala, M.; Monsalvo, Á.; Betancourth, C.; Salazar, C.; Lagos, T. (2011). Evaluación de Solanaceas silvestres como patrones de lulo (Solanum quitoense Lam) y su reacción a Fusarium sp. Revista de Ciencias Agrícolas. 28(1): 147-160.

Avila, A.; Ochoa, J.; Proaño, K.; Martínez, M. (2019). Jasmonic acid and nitric oxide protects naranjilla (Solanum quitoense) against infection by Fusarium oxysporum f. sp. quitoense by eliciting plant defense responses. Physiological and Molecular Plant Pathology. 106: 129-136. doi: https://doi.org/10.1016/j.pmpp.2019.01.002

Buitrago, M. (2018). Identificación morfológica y molecular de Fusarium aislados del cultivo de la piña de la provincia de panamá oeste. Retrieved from http://up-rid.up.ac.pa/1442/

Betancourth, C.; Zambrano, M.; Narváez, C. (2005). Reacción de diferentes genotipos de lulo (Solanum quitoense) al ataque de Fusarium oxysporum. Revista de Ciencias Agrícolas. 22(12).

Cardona, L.; Castaño, J. (2019). Comparación de métodos de inoculación de Fusarium oxysporum f. sp. lycopersici (Sacc.), causante del marchitamiento vascular del tomate. Revista de la Academia Colombiana de Ciencias Exactas, Físicas y Naturales. 43(167): 1-227. doi: https:// doi.org/10.18257/raccefyn.854

Carvalho, J.; Gonçalves, J.; Araujo, K.; Serafim, M.; Santana, T.; Grillo, L. (2021). Passion Fruit (Passiflora spp.) species as sources of resistance to soil phytopathogens Fusarium solani and Fusarium oxysporum f. sp. passiflorae complex. Revista Brasileira de Fruticultura. 43(1): e-427. doi: https://doi.org/10.1590/010029452021427
Castro, L. W.; Carrera, S. K.; Herrera, I. L; Cupull, S. R. (2018). Identificación de aislados de Fusarium spp. Asociados a Solanum quitoense Lam. En Pastaza, Ecuador. Revista Centro Agrícola. 45(4):1-11.

CIAT - Centro Internacional de Agricultura Tropical. (2010). Informe final técnico proyecto "Productores de lulo y mora competitivos mediante selección participativa de clones élite, manejo integrado del cultivo y fortalecimiento de cadenas de valor Fontagro Mora Lulo. Retrieved from https://www.fontagro.org/new/uploads/ adjuntos/616-06-InformeTecnicoFinal.pdf

Duarte-Alvarado, D.; Lagos-Santander, L.; Lagos-Burbano, T. (2020). Patogenicidad de aislamientos de Fusarium oxysporum en Lulo (Solanum quitoense Lam.). In: Lagos-Burbano, T. Mejoramiento Genético de Lulo (Solanum quitoense Lam.). pp. 203 - 218. Primera edición. Pasto, Nariño: Editorial Universitaria, Universidad de Nariño. 253p.

Estupiñan, H.; Ossa, J. (2007). Efecto del Agente Causal de la marchitez vascular de la uchuva (Physalis peruviana) el hongo Fusarium oxysporum Schlecht, sobre algunas Solanaceas y otras especies cultivadas afectadas por formas especiales del microorganismo. Colombia: Pontificia Universidad Javeriana. 89p.

Espinoza-Ahumada, C.; Gallegos-Morales, G.; Hernández-Castillo, F.; Ochoa-Fuentes, Y.; Cepeda-Siller, M.; Castillo-Reyes, F. (2019). Antagonistas microbianos a Fusarium spp., como agente causal de pudrición de raíces y tallo en melón. Ecosistemas y Recursos Agropecuarios. 6(16):45-55. doi: https://doi.org/10.19136/era. a6n16.1843

Forero, R.; Ortíz, E.; León, E.; Gómez, J.C.; Carvajal, L. (2015). Análisis de la resistencia a Fusarium oxysporum en plantas de Passiflora maliformis $\mathrm{L}$. Rev. Col. Ciencias Hortícolas. 9(2):197- 208.

Forero-Reyes, C.; Alvarado-Fernández, A.; CeballosRojas, A.; González-Carmona, L.; Linares-Linares, M.; Castañeda-Salazar, R.; Pulido-Villamarín, A.; Góngora-Medina, M.; Cortes-Vecino, J.; Rodríguez- 
Bocanegra, M. (2018). Evaluación de la capacidad patogénica de Fusarium spp. en modelos vegetal y murino. Revista Argentina de Microbiología. 50(1): 90-96. doi: https://doi.org/10.1016/j. ram.2016.11.009

Gabriel, J.; Indacochea, B.; Ayon, F.; Valverde, A.; Vera, M.; Castro, C.; Manibanda, M. (2020). Principios Básicos de la Resistencia genética a patógenos, plagas y factores abióticos. Jipijapa, Ecuador: Universidad Estatal del Sur de Manabí (UNESUM), Grupo COMPAS. 116p.

Gallardo, A. S. (2005). Métodos de manejo del cultivo de naranjilla (Solanum quitense Lam.) para el control de Fusarium oxysporum en Ecuador. Retrieved from https://repositorio.iniap.gob.ec/ bitstream/41000/287/1/iniapsctG162m.pdf

García, J. M.; Shagarodsky, T.; Fresneda, J.A.; Fundora, Y.H.; González, J. (2007). Caracterización de especies del género Fusarium en el cultivo del garbanzo (Cicer arietinum) en las provincias ciudad Habana y La Habana. Temas de Ciencia y Tecnología. 32(11):63-66.

Gonzales, I.; Arias, Y.; Peteira, B. (2012). Aspectos generales de la interacción Fusarium oxysporum f. sp. Lycopersici - Tomate. Rev. Protección Veg. 27(1): 1-7.

Guerra-Fuentes, N.; Chávez-Bautista, M.; TreviñoEspinosa, R.; García-Mazcorro, J.; Torres-Castillo, J.; Méndez-Albores, A.; Marroquín-Cardona, A. (2019). Effects of Neutral Electrolysed Water on tomato seeds artificially contaminated with Fusarium and Aspergillus. Seed Science and Technology. 47(2):211-227. doi: https://doi. org/10.15258/sst.2019.47.2.08

Hernández, C.; Vásquez, J.; Vásquez, F.; Berdeja, R.; Morales, S.; Reyes, D. (2020). Abundancia y diversidad genética de Fusarium oxysporum y Trichoderma sp. en musa AAB. Revista Mexicana de Ciencias Agrícolas. 10(8):14.

Huarhua, M. (2018). Razas de Fusarium oxysporum f. sp. lycopersici aisladas de tomate (Solanum lycopersicum) proveniente de costa central del Perú. Retrieved from http://repositorio. lamolina.edu.pe/handle/UNALM/3513

IDEAM - Instituto de Hidrología, Meteorología y Estudios Ambientales. (2020). Informe de precipitaciones y temperatura del 2019. Retrieved from https://n9.cl/rktiu

Iturbide-Zuñiga, A.; Colinas-León, M.; LozoyaSaldaña, H.; Medina-Moreno, S.; Ayala-Arreola, J. (2017). Evaluación in vitro de extractos del genero Lilium para el control de Fusarium oxysporum. Revista mexicana de fitopatología. 35(3): 611-622. doi: https://doi.org/10.18781/r. mex.fit.1609-6

Lagos, T. C.; Apráez, J.; Lagos, L.; Duarte, D. (2015). Comportamiento de 50 familias de medios hermanos de Solanum quitoense Lam, bajo selección recurrente. Temas Agrarios. 20(2):1929. doi: https://doi.org/10.21897/rta.v20i2.755

Leslie, F.; Summerell, B. (2006). The Fusarium Laboratory Manual. Manhattan, United States of America: Published, Blackwell. 387p.

Leyva-Mir, S.; Gutiérrez-Salazar, J.; Camacho-Tapia, M.; Aguilar-Pérez, L.; García-López, E.; TovarPedraza, J. (2018). Fusarium oxysporum, agente causal de la marchitez de estevia en Veracruz, México. Revista mexicana de ciencias agrícolas. 9(1): 245-250. doi: https://doi.org/10.29312/ remexca.v9i1.863

López-Zapata, S.; Castaño-Zapata, J. (2019). Manejo integrado del mal de Panamá Fusarium oxysporum Schlechtend.: Fr. sp. cubense (E.F. SM.) W.C. Snyder \& H.N. Hansen: una revisión. Rev. UDCA actual. Divulg. Cient. 22(2):e1240. doi: http://dx.doi. org/10.31910/rudca.v22.n2.2019.1240

Manangon, M. L.; Ochoa, L.; Clavijo, F. (2015). Patogenicidad de Fusarium oxysporum f.sp quitoense en la Sección Lasiocarpa. Retrieved from https://repositorio.iniap. gob.ec/bitstream/41000/2445/1/iniapscP. M266p2008.pdf

Mariscal-Amaro, l.; Rivera-Yerena, A.; DávalosGonzález, P.; Avila-Martínez, D. (2017). Situación actual de hongos asociados a la secadera de la 
fresa (Fragaria × ananassa Duch.) en Guanajuato, México. Agrociencia. 51(6):673-681.

Maya, C.; Lagos, T. (2011). Comportamiento de 70 familias de medios hermanos ( $\mathrm{mh}$ ) de lulo castilla (Solanum quitoense Lam) ante la inoculación artificial de Fusarium spp. Retrieved from http:// sired.udenar.edu.co/5229/

MADR - Ministerio de Agricultura y Desarrollo Rural. (2019). Red de Información y Comunicación del Sector Agropecuario de Colombia, Reporte: Área, producción y rendimiento nacional por cultivo. Retrieved from https://www.agronet.gov.co/ estadistica/Paginas/home.aspx?cod=1

Nelson, P. E.; Dignani, M. C.; Anaissie, E.J. (1994). Taxonomy, Biology, and Clinical Aspects of Fusarium species. Clin. Microbial. Rev. 7(4):479504. doi: 10.1128/cmr.7.4.479

Ochoa, J. (2002). Seed Transmission of Fusarium oxysporum in Common Naranjilla (Solanum quitoense) in Ecuador. Online. Plant health progress. doi: 10.1094/PHP-2002-0719-01-HN

Ochoa, j.; Yangari, B.; Galarza, V.; Fiallos, J. (2001). Vascular wilt of common Naranjilla (Solanum quitoense) caused by Fusarium oxysporum in Ecuador. Plant Health Progress. doi: 10.1094/ PHP-2001-0918-01-HN

Piñeros-Guerrero, N.; Maldonado-Archila, G., GómezCaro, S. (2019). Effect of thermal and in vitro fungicide treatments on pathogens of the genus Fusarium associated with maize seeds. Agronomía Colombiana. 37(3):228-238. doi: https://dx.doi. org/10.15446/agron.colomb.v37n3.80302

Rentería-Martínez, M.; Guerra-Camacho, M.; OchoaMeza, A.; Moreno-Salazar, S.; Varela-Romero, A.; Gutiérrez-Millán, l.; Meza-Moller, A. (2018). Análisis filogenético multilocus del complejo fúngico asociado a pudrición radicular de sandía en Sonora, México. Revista mexicana de fitopatología. 36(2): 233-255. doi: https://doi. org/10.18781/r.mex.fit.1710-1

Retana, K.; Ramírez-Coché, J.; Castro, O.; BlancoMeneses, M. (2018). Caracterización morfológica y molecular de Fusarium oxysporum f. sp. apii asociado a la marchitez del apio en Costa Rica. Agronomía Costarricense. 42(1):115-126. doi: https://dx.doi.org/10.15517/rac.v42i1.32199

Ribeiro, I.; Silva, S.; Santos de Oliveira, S.; Amorim, E.; Perito, J.; Haddad, F. (2018). Sources of resistance to Fusarium oxysporum f. sp. cubense in banana germplasm. Revista Brasileira de Fruticultura. 40(1): e-202. doi: https://doi. org/10.1590/0100-29452018202

Robles-Carrión, A.; Leiva-Mora, M.; Herrera-Isla, I.; Sánchez-Rodríguez, A.; Torres-Gutiérrez, R. (2016). Morphological and molecular identification of Fusarium species associated with vascular wilt of babaco (Vasconcellea heilbornii var. pentagona Badillo). Revista de Protección Vegetal. 31(3): 184-193.

Segura, B.; Torres, G. (2020). Evaluación de planes de manejo de Fusarium oxysporum f. sp en plantas de tomate, bajo condiciones controladas. Retrieved from https://repository.unad.edu. co/bitstream/handle/10596/36796/bsegurao. pdf? sequence $=3$ \&isAllowed $=y$ 